\title{
KONSEP DAN APLIKASI PROFESI KEGURUAN
}

\author{
Akhmad Saifi \\ Email: 2010111210009@mhs.ulm.ac.id \\ Program Studi Pendidikan Sejarah Fakultas Keguruan dan Ilmu Pendidikan \\ Universitas Lambung Mangkurat \\ Banjarmasin
}

\begin{abstract}
Abstrak
Profesi dapat diartikan sebagai suatu pekerjaan maupun Jabatan yang menuntutabatan yang menuntut keahlian atau skill yang didapat, melalui berbagai macam pendidikan dan latihan tertentu menuntut persyaratan-persyaratan khusus memiliki tanggung jawab dan kode etik tertentu. Profesi guru adalah penddik professional dengan tugas utama mendidik mengajar dan membibing mengarahkan melatih dan menilai, mengevaluasi peserta didik pada pendidikan anak usia dini jalur pendidikan formal pendidikan dasar dan pendidikan menengah. Guru digolongkan sebagai profesi karena menurut keahlian dan persyaratanpersyaratan khusus dalam melaksanakan tugas nya memiliki organisasi profesi kode etik, dan memiliki wadah organisasi, peran hak dan kewajiban guru membimbing mengarahkan peserta didik serta mengevaluasi proses belajar-mengajar yang baik dan terarah secara khusus. Komponen yang wajib dimiliki oleh guru: kompetensi pedagogic, kompetensi professional guru, kompetensi sosial guru dan kompetensi kepribadian guru harus memilii semua kompetensi itu.
\end{abstract}

\section{PENDAHULUAN}

Profesi secara etimologi dari kata profession (Inggris) yang berasal dari bahasa Latin Profesus yang bearti "mampu atau ahli dalam suatu bentuk pekerjaan". Profesi dapat diartikan sebagai suatu pekerjaan atau jabatan yang menurut keahlian, yang didapat melalui pendidikan dan latihan tertentu, menurut persyaratan khusus memiliki tanggung jawab dan kode etik tertentu 
(Susanto 2020:13)

Profesi Guru berdasarkan UU RI No.14 tahun 2005 tentang guru dan dosen pasal 1, Guru adalah pendidikan profesional dengan tugas utama mendidik, mengajar, membimbing, mengarahkan, melatih, menilai, dan mengevaluasi peserta didik pada pendidikan anak usia dini jalur pendidikan formal, pendidikan dasar, dan pendidikan menengah. (Susanto 2020:16)

\section{PERAN GURU SEBAGAI SEBUAH PROFESI}

Guru merupakan suatu profesi, yang bearti suatu jabatan yang memerlukan keahlian khusus sebagai guru dan tidak dapat dilakukan oleh orang sembarang orang diluar bidang pendidikan. Walaupun pada kenyataannya masih terdapat guru yang tidak memiliki latar belakang pendidikan bidang keguruan. (Susanto 2020:17)

Berdasarkan UU RI No.14 tahun 2005 tentang guru dan dosen, guru adalah pendidikan profesional dengan tugas utama mendidik, mengajar, membimbing, mengarahkan, melatih, melatih, menilai, dan mengevaluasi peserta didik pada pendidikan anak usia dini jalur pendidikan formal, pendidikan dasar, dan pendidikan menengah. Dosen adalah pendidik profesional dan ilmuan dengan tugas utama mentransformasikan, mengembangkan, dan menyebarluaskan ilmu pengetahuan, teknologi, dan seni melalui pendidikan, penelitian, dan pengabdian kepada masyarakat. Menurut Noor Jamaluddin (1978:1) Guru adalah pendidik, yaitu orang dewasa yang bertanggung jawab memberi bimbingan atau bantuan kepada anak didik dalam perkembangan jasmani dan rohaninya agar mencapai kedewasaannya, mampu berdiri sendiri dapat melaksanakan tugasnya sebagai makhluk Allah khalifah di muka bumi, sebagai makhluk sosial dan individu yang sanggup berdiri sendiri. Sedangkan Rickey (1987) sebagaimana dikutif Soetjipto dan Kosasi (2009:17) mengemukakan ciri-ciri guru sebagai profesi, yaitu:

1) Adanya komitmen dari para guru bahwa jabatan itu mengharuskan pengikutnya mengungkung tinggi martabat kemanusiaan lebih dari pada mencari keuntungan diri sendiri.

2) Suatu profesi menyaratkan orangnya mengikuti persiapan profesional dalam jangka waktu tertentu. 
3) Harus selalu menambah pengetahuan agar terus menerus berkembang dalam jabatannya.

4) Memiliki kode etik jabatan.

5) Memiliki kemampuan intelektual menjawab masalah-masalah yang dihadapi.

6) Selalu ingin belajar terus-menerus mengenai bidang keahlian yang ditekuni.

7) Menjadi anggota dari suatu organisasi profesi.

8) Jabatan itu dipandang sebagai suatu karir hidup. (Susanto 2020:16/17)

\section{GURU INDONESIA DAN TANTANGAN PROFESIONALISME}

Profesionalisme diperlukan untuk memajukan pendidikan di negara Indonesia karena professional mengadung arti yang berkualitas tinggi dalam hal teknis, kemampuan guru dalam beberapa bagian: kemampuan merencankan pengajaran, kemampuan melaksanakan prosedur mengajar kemampuan melaksanakan hubungan dengan siswa. Kemudian guru yang bersifar profesionalisme tentu memiliki keahlian dalam bidangnya seorang guru itu ahli dalam bidang yang diajarkan dan ahli dalam tugas mendidik, seorang guru tentu saja tidak hanya menguasai materi pembelajaran yang diajarkan tetapi juga mampu dalam menanamkan konsep tentang pengetahuan yang diajarkan nya, pemahaman konsep dapat dikuasai bilang guru memahami psikologi mengajar. Profesionalisme sangat diperlukan dalam memajukan pendidikan di Indonesia tentu juga sebagai perilaku kerja yang mengutamakan kesempurnaan hasil dengan menjalankan mekanisme kerja yang benar, hal ini sangat diperlukan untuk menunjang pendidikan Indonesia guru yang benar, hal ini sangat diperlukan untuk menunjang pendidikan Indonesia guru yang profesional berorientasi pada klien, dan menunjukan sikap tanggung jawab pada pekerjaan. Untuk dapat menjalakan suatu pekerjaan secara profesional atau memilki profesinalisme sidang tentu diperlukan seperangkat pengetahuan, sikap dan keterampilan tertentu. Tentu guru yang profesionalisme dapaat membuat pendidikan menjadi lebih berkembang sehingga, lebih bagus untuk masa depan negara Indonesia yang mana memiliki kompetensi keahlian dibidangnya (Susanto.H:56-62)

Berkaitan dengan definisi kompetensi dan profesionalisme, setiap individu yang menjalankan profesi wajib memiliki kompetensi sesuai dengan bidang profesinya. Profesi 
guru dalam undang-undang No.14 tahun 2005 tentang guru dan dosen mengharuskan sebuah komponen pokok yang harus dimiliki seorang guru profesional, kompetensi tersebut adalah; kompetensi profesional, kompetensi pedagogik, kompetensi sosial, dan kompetensi kepribadian

\section{Kompetensi Profesional guru}

Kompetensi profesional guru berasal dari dua kata yaitu kompetensi dan profesional. Pengertian dasar kompetensi adalah kemampuan atau kecakapan. Dalam arti lain kompetensi profesional guru ialah kemampuan dan kewenangan guru dalam menjalankan profesi keguruannya, artinya guru yang piawai dalam melaksanakan profesinya dapat disebut sebagai guru yang kompeten dan profesional. Kompetensi profesional merupakan pekerjaan yang hanya dapat dilakukan oleh seorang yang mempunyai kualifikasi akademik, kompetensi dan sertifikat pendidik sesuai dengan persyaratan unutk pendidikan tertentu.

2. Kompetensi pedagogik guru

Pedagogik adalah teori mendidik yang mempersoalkan apa dan bagaimana mendidik sebaik baiknya. (Suardi, 1979:113) sedangkan menurut pengertian Yunani pedagogik adalah ilmu menuntuk anak yang membicarakan masalah atau persoalan-persoalan dalam pendidikan dan kegiatan-kegiatan mendidik, tugas guru yang utama adalah mengajar dan mendidik murid dikelas maupun diluar kelas guru selaln-persoalan dalam pendidikan dan kegiatan-kegiatan mendidik, tugas guru yang utama adalah mengajar dan mendidik murid dikelas maupun diluar kelas guru selaln-persoalan dalam pendidikan dan kegiatan-kegiatan mendidik, rugas guru yang utama adalah mengajar dan mendidik murid dikelas maupun diluar kelas guru selalu berhadapan dengan murid yang memerlukan pengetahuan, keterampilan dan sikap utama untuk menghadapi hidupnya dimasa depan. Dilihat dari proses pembelajaran kompetensi pedagogik merupakan kemampuan guru dalam pengelolaan perkembangan pembelajaran peserta didik. Hal ini harus mampu diwujudkan oleh setiap guru untuk kehidupan bangsa.

\section{Kompetensi sosial guru}

Merupakan kemampuan guru untuk memahami dirinya sebagai bagian dari masyarakat dan mampu mengembangkan tugas sebagao, anggota masyarakat dan warga negara (satori dkk, 2008:215). Dengan memahami dan menerapkan nilai dan norma yang 
berlaku dimasyarakat karen guru merupakan bagian dari masyarakat, selain itu dalam hal memenuhi tanggung jawab sebagai mana yang diatur, dalam pembukaan undang-undang dasar negara Republik Indonesia pada alinea keempat. Berkomunikasi lisan dan tertulis, menggunakan teknologi informasi komunikasi secara fungsional, bergaul secara aktif dengan pesesrta didik, sesama pendidik, tenaga pendidikan, orang tua atau wali peserta didik, serta bergaul secara santun masyarakat disekitar

\section{Kompetensi kepribadian guru}

Merupakan salah satu jenis kompetensi yang perlu dikuasai seorang guru selain 3 jenis kompetensi lainnya; sosial, pedagogik dan profesional. Dalam penjelasan peraturan pemerintah no19 tahun 2005 tentang standar nsaional pendidikan disebutkan bahwa kompetensi kepribadian guru yaitu kepribadian yang mantap, stabil, dewasa, Arif dan bijaksana, berwibawa, berakhlak mulia dan mengembangkan diri secara berkelanjutan sementara itu menurut pemendikas N0.16 tahun 2007 tentang kualifikasi dan kompetensi guru menjelaskan kompetensi kepribadian untuk guru kelas dan guru mata pelajaran pada semua jenjang, pendidikan dari dasar hingga menengah.

\section{(Amirudin, Konsep, Pendidik:80-84)}

\section{SIMPULAN}

Profesi diartikan sebagai suatu pekerjaan yang bersifat profesional, profesi guru memiliki tanggung jawab dalam meningkatkan pendidikan, guru digolongkan dalam sebuah profesi sebab diharuskan memilki persyaratan-persyaratan khusus dibidang pendidikan oleh karena itu peran hak dan kewajiban guru adalah membimbing mengarahkan, mendidik peserta didik serta membekali ilmu pengetahuan. Maka diperlukan keprofesionalisme dalam menjalankan fungsi dan membimbing peserta didik, kompetensi guru yang profesinoal adalah orang yang memiliki kemampuan dan keahlian tugas dang fungsinya sebagai guru dengan maksimal. Ada 4 jenis kompetensi guru pertama kompetensi pedagogik yaitu kemampuan mengelola pembelajaran peserta didik yang meliputi pemahaman terhadap peserta didik perencanaan dan pelaksanaan pembelajaran, mengevaluasi hasil belajar serta pengembangan peserta didik unutk mengatualisasikan potensi yang dimiliki. Kedua kompetensi kepribadian yaitu kemampuan personal yang mencerminkan kepribadian yang mantap dan stabil berakhlak 
mulia dewasa Arif berwibawa serta teladan bagi peserta didiknya. Ketiga kompetensi profesional yaitu kemampuan penguasaan materi pembelajaran secara mendalam yang mencakup penguasaan materi kurikulum mata pelajaran disekolah dan subtansi keilmuan yang menaungi materiny, serta penguasaan terhadap struktur dan metodologi keilmuannya, Keempat kompetensi sosial yaitu kemampuan guru untuk berkomunikasi dan berinterasksi secara efektif dan efisien dengan peserta didik sesama pendidik dan tenaga kependidikan, orang tua atau wali peserta didik serta masyarakat sekitar yang tergabung didalamnya

\section{REFERENSI}

Efendi, I., Prawitasari, M., \& Susanto, H. (2021). Implementasi Penilaian Pembelajaran Pada Kurikulum 2013 Mata Pelajaran Sejarah. Prabayaksa: Journal of History Education, 1(1), 21-25.

Susanto, H. (2020). Profesi Keguruan. Banjarmasin: FKIP Universitas Lambung Mangkurat.

Susanto, H., \& Akmal, H. (2018). Efektivitas Penggunaan Aplikasi Pembelajaran Berbasis Mobile Smartphone Sebagai Media Pengenalan Sejarah Lokal Masa Revolusi Fisik Di Kalimantan Selatan Pada Siswa Sekolah Menengah Atas. HISTORIA: Jurnal Program Studi Pendidikan Sejarah, 6(2), 197-206.

Susanto, H., Irmawati, I., Akmal, H., \& Abbas, E. W. (2021). Media Film Dokumenter Masuknya Islam Ke Nusantara dan Pengaruhnya Terhadap Keterampilan Berpikir Kritis Siswa. HISTORIA: Jurnal Program Studi Pendidikan Sejarah, 9(1).

Syaharuddin, S., \& Susanto, H. (2019). Sejarah Pendidikan Indonesia (Era Pra Kolonialisme Nusantara sampai Reformasi). Banjarmasin: FKIP Universitas Lambung Mangkurat.

Mulyasa,E. 2006. Menjadi Guru Profesional: (Menciptakan Pembelajaran Kreatif, dan Menyenangkan). Bandung: PT Remaja Rosdakarya 
Sutomo. 1997. Profesi Kependidikan. Semarang:IKIP Semarang Rajawali Press.

Hamzah. B. Uno. 2008. Profesi Keguruan, Problema, Solusi, dan Reformasi pendidikan di Indonesia, Cet.II. Jakarta: PT. Bumi Aksara. 